\title{
Protection from Bankruptcy in the Acquisition Process
}

\author{
Marcin Halicki*
}

\begin{abstract}
Purpose - the aim of the paper is to present a scheme, which was developed for the analysis of acquisitions in terms of protection from bankruptcy. It was also shown that the scheme can be used in calculating the number of shares, the purchase of which will not be the subject, in theory, to bankruptcy. Design/methodology/approach - For the development of the proposed scheme, the authors used literature and tools- based on financial engineering, and the calculations were carried out on hypothetical data.

Findings - Our calculations show that the proposed scheme can be used for the assessment acquisitions of companies; however, it should be taken into account that a number of important assumptions may significantly affect the final evaluation.

Originality/value - The development can be considered as complementary to current knowledge on mergers and acquisitions. You can recognize them also as a contribution to separate quantitative research and a voice in the discussion, needed for the development of the subject work.
\end{abstract}

Keywords: mergers, acquisitions, bankruptcy, risk, shares, EPS

\section{Introduction}

Globalization is a fact and the impact on the economy is increasingly forcing companies to enter an increasingly higher level of competition. The result derived from this is the growing role of M\&A transactions within the management of undertakings, which in principle should be part of implementing their strategic goals. Considering the above-mentioned transactions theoretically, it should be noted that one can list some main themes. These include: the desire to enlarge the wealth of shareholders, the increase in market value after a merger, the search for synergies arising from, for example, cost reduction or growth enlargement and the reduction of the risk (Damodaran, 2007, pp. 1267-1278). Research confirms the fact that even pride (Roll, 1986, pp. 197-216) is a motivator to take over businesses.

Narrowing down the discussion only to taking control of public limited companies and aside from the effectiveness of such transactions, which the rational reasons may be characterized by low economic efficiency, as well as the motives of their conclusion, studies of the literature suggest that there developed a scheme, which would allow for the analysis of acquisitions for avoiding bankruptcy (after the merger's acquisition). Such a scheme,

\footnotetext{
* dr Marcin Halicki, Uniwersytet Rzeszowski, Wydział Biologiczno-Rolniczy, Zakład Polityki Regionalnej i Gospodarki Żywnościowej, e-mail: mhalicki@ur.edu.pl.
} 
especially from the perspective of the acquiring company, can be considered interesting for two reasons. First and foremost, it allows determining whether taking control of the acquired company may in the long run contribute to bankruptcy after the merger. Secondly, this scheme would be useful in the context of determining the precise number of shares; whose acquisition by the acquiring company does not bring about the bankruptcy. There is no need to explain more that gaining control over an acquired company does not rely on a combination in a full sense of the word, but on the acquisition of the controlling stake. In this case, the transferee shall have the rights and obligations of the company's partner. With all this in mind and wanting to fill the presented cognitive gap, the authors have made an attempt to develop such a scheme, using the tools of financial engineering. They used the subject literature and their own considerations based on hypothetical data. In order not to complicate the argument, the discussion was limited to the analysis of joint stock companies.

\section{Brief characteristics of the area of mergers and acquisitions}

Characterizing the essence of mergers and acquisitions, in the first place there should be mentioned the fact that this area can be described and tested for different shots, even resulting from material literature, which makes the basis for the considerations, or from legislation and accounting rules. Because in addition to the acquisitions, one can also stand out the connections, and the latter are superficially worth devoting attention to, even for a better understanding of the raised issues. It is enough to mention that English literature, by using terms "Mergers and Acquisitions" (abbreviated M\&A), suggests the division of the study area in two such approaches. Narrowing the discussion to the Polish legal realities and the accounting standards binding in Poland, this area can be divided into two areas (Frąckowiak, 1998, p. 20):

- mergers - result in the fact that from two or more business entities, there is only one left. As a part of the call, there may occur fusions (when one of the merging parties does not lose legal personality) or consolidations (the merging entities lose their legal status to the newly created entity based on them),

- acquisitions - the result, as the name suggests, is to take on the business, wherein the overtaken business entity does not lose its legal personality, this process occurs through the purchase of shares (shares), property, etc.

As it can be seen, the work has not been the subject of the integration of enterprises, which is dictated by the fact that the mentioned concept, though important from the point of view of a financial management company, applies to the steps following the merger or acquisition. From the point of view of the paper's aims, the characteristics of this subject are therefore not needed. It was mentioned in the introduction that there are many different themes of transactions of mergers and acquisitions. However, the problem lies in the fact that the analysis of the study matter showed that the literature in the area of mergers and acquisitions, which focused on economic performance, after the operations were carried 
out, confirms the fact that most of them resulted more in reduction than in an increase in the value of the entity which was created after such transactions (Dickerson, Gibson, Tsakalotos, 1997, pp. 344-361). However, they may result in the effective transfer of knowledge (Ahuja, Katila, 2001, pp. 197-220) very useful in a globalizing era based on the information.

Let there be, however, expressed the view that the market of mergers and acquisitions will continue to grow not only because of the aforementioned reasons. There are two additional reasons for the merger of enterprises, especially in debt and operating in the market for a long time period ${ }^{1}$. Firstly, the merger with an indebted one makes the debt become a debt of the company formed after the merger. Such an undertaking results in lower income tax payments. Secondly, if an indebted company did not settle liabilities from supplies and services, then after the combination it can begin negotiations with suppliers to reduce the payment for the goods received. Then, being known in a given market, the company can try to acquire a trade credit, and therefore it becomes easier to get a foothold in new markets by reducing entry barriers.

\section{A classical approach to a merger}

Before we present the scheme for the possibility of taking control over a company without endangering bankruptcy, first we should present a classical, and often presented in the literature, approach of the connection that follows the current market prices of shares through the issuance of shares (shares) of the company acquiring the shares of the acquired company. It is therefore the transfer of the assets of the latter to the former (Perepeczko, 2009, p. 14). This necessity is dictated by the fact that the classical approach is related to the number of shares, which the shareholders of the acquired company are entitled to in exchange for shares of the acquiring company. In such a case it does not calculate the value of a controlling stake, i.e. the number of shares that allow for effective control. It will be clearly noticed that in the so-understood connection it cannot be treated as an investment, so the scheme of the protection against bankruptcy cannot be used because there appears a complete connection, or the lack of thereof. Despite this, it is worth presenting the classical approach to understand the idea of mergers, especially for the reason that it is also not often presented in the literature. The data used for its development are also needed, as they had been used to develop an approach taking into account protection against bankruptcy in the process of taking over a controlling stake.

The classical approach is worth illustrating with the theoretical example of a hypothetical merger of two companies, for the fact to organize common sense knowledge. Thus it was assumed that the combination of a (X company and Y company) follows the current market prices of shares (as mentioned in the earlier part of the work). Table 1 shows the data

\footnotetext{
${ }^{1}$ It is difficult to determine at this point the period of business. It is mainly about the fact of being well known in the area or in a particular segment, for example, among suppliers.
} 
that are needed for both the classical approach, as well as the proposed scheme. They will be also used in another part of the paper. They were prepared in a manner to preserve the transparency of the results and highlight the most important aspects, not only because of the traditional approach, but also due to the following presented sequence scheme.

\section{Table 1}

Key financial data of company $\mathrm{X}$ and company $\mathrm{Y}$

\begin{tabular}{lll}
\hline Indicator & Company X & Company Y \\
\hline Book value per share & 30 & 20 \\
Price-to-Earnings Ratio (P/E) & 9 & 8 \\
Initial total number of shares (in millions) & 4 & 2 \\
Debt/Equity Ratio & 1 & 1 \\
Net income (in millions of USD) & 6 & 4 \\
Earnings per share (EPS) (in USD) & 1.5 & 2 \\
Cash in current asset (in millions of USD) & 54 & 32 \\
\hline
\end{tabular}

Source: own study.

In the case of the recognized classical approach, the only problem may be associated with determining the number of additional shares of company $\mathrm{X}$, where emissions are needed to make the merger. The shares of the acquiring company are entitled for shareholders of the acquired company (company Y) in exchange for shares of the acquired company. It is easy to conclude first of all the calculated market price of the shares for both companies (according to the following formula) must be done:

$$
\text { Share price }=\left(\frac{P}{E} \times \text { Net income }\right) /(\text { Total number of shares }),
$$

Then, there needs to be a specified the number of shares in company $\mathrm{X}$, which must issue a goal merger. To do this, use the following formula:

$$
P_{X} \times N_{X}=P_{Y} \times N_{Y},
$$

where:

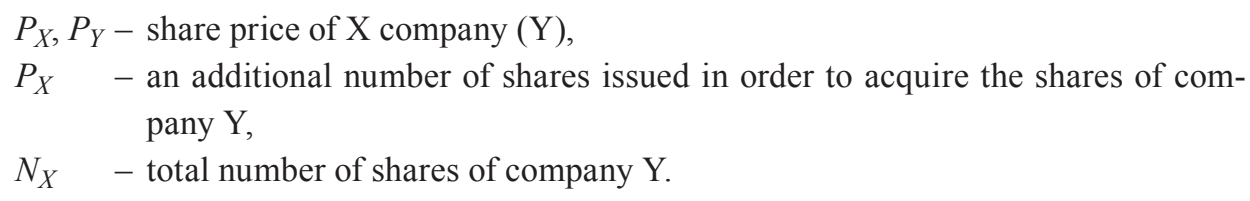

Transforming the pattern shown above, we obtain the number of additional shares, which is vital to the goal, a merger, and therefore:

$$
N_{X}=\left(P_{Y} \times N_{Y}\right) / P_{X} .
$$


Knowing the number of additional shares, we can calculate the market value of the equity of the company after the merger (if the taking over entity is company $\mathrm{X}$ ):

Market value of equity $=P_{X} \times\left(N_{X}+\right.$ initial total number of shares of company $\left.\mathrm{X}\right)$.

On the basis of hypothetical data, the calculations were carried out using the specified package designs. Their results are presented in Table 2 .

Table 2

Key financial data after the merger of company $\mathrm{X}$ and company $\mathrm{Y}$

\begin{tabular}{lcc}
\hline Indicator & Company X & Company Y \\
\hline Share price (in USD) & 13.5 & 16 \\
$N_{X}$ (in millions) & 2.37 & - \\
\hline & \multicolumn{2}{c}{ The company after the merger } \\
\hline Market value of equity (in millions of USD) & \multicolumn{2}{c}{86.00} \\
Total number of shares (in millions) & 6.37 \\
Net income (in millions of USD) & 10.00 \\
Earnings per share (EPS) & 1.57 \\
\hline
\end{tabular}

Source: own study.

Analysing the data presented in Table 2, in the first place it is noted that after the merger, the market price of the shares has not changed, however the value of equity has increased (due to the issuance of shares) and the value of the indicator 'EPS' has changed. In this case, the value has increased, which is defined as anti-dilution (IAS 33). There is presented a method for calculating it, as it is commonly known. The classical approach, which devotes the most attention, as reflected in the rich material literature, is associated, however, with some potential drawbacks that limit the optimal financial management and thereby reduce the possibility of increasing the company's value and the wealth of shareholders - understood as the recognition of Damodaran (Damodaran, 2007, p. 1388). They include:

- the lack of protection against bankruptcy, which may occur after the merger,

- the merger may result in a decrease in the indicator 'EPS', referred to as dilution, which is seen by investors as a negative phenomenon,

- the lack of synergies, which could cause a decline in the market value of the equity after the merger.

Considering the above, taking over the company it is worth considering a different approach, consisting in the acquisition. As everyone knows, it may occur through the repurchase of shares acquired through its own cash or supporting the debt. However, there cannot be overlooked the fact that the acquisition of companies is characterized by high credit ratings associated with the high outflow of cash (Surendranath, Thanh, Ngo, Wang, 2016, pp. 93-104), which may risk the loss of liquidity of the absorbing entity. Therefore, the 
approach based on the protection against bankruptcy may be considered desirable, but it requires corresponding calculations, which cannot be found in the literature.

\section{The acquisition of the controlling stake and protection from bankruptcy}

The takeover of controlling interest is tantamount to taking control over the company, thus it involves the release of funds in order to acquire the company, and therefore the value of assets is automatically reduced. Moreover, this reduction automatically enlarges the widely understood risk assets of the company leading to a reduction of liquidity, and this is a buffer that protects against bankruptcy. Taking control can therefore be considered as an investment which exposes the bankruptcy of the acquiring company, and therefore protection against it is a priority objective of financial management in the course of such transactions, and the development of the scheme allowing for it, can be considered cognitively interesting.

Before the presentation of the indicated scheme, there should be asked a question, what is the expected income that will be generated after the merger and accompanied by the risk (not uncertainty)? It is extremely important from the point of view of the application of the mathematical apparatus, which is based on the model of Foster-Hart (Foster, Hart, 2009, pp. 785-814), because only it allows, as confirmed by studies already carried out in literature (Halicki, 2016, pp. 205-216), to determine the minimum required value of wealth (in this case, that is, the cash of a company), which must be a protective shield against bankruptcy in the case of acquisition of investment at certain projected income data probabilities. As it can be seen, the question of defining income plays a central role in the construction of the proposed scheme, because without it, it is not possible to apply the Foster-Hart formula, whose character is as follows:

where:

$$
E\left[\log \left(1+\frac{1}{R(g)} g\right)\right]=0,
$$

$g$ - means the income from investments, which is obtained with a certain probability at the end of the investment period, while the $R(g)$ is the minimum value of the cash that must be possessed not to become bankrupt (this is also a measure of the investment risk).

It can be noticed that the development of the mentioned scheme had required to indicate what was the income of the company after the merger, which in the Foster-Hart theory is defined as the income received by the end of the investment period, because its variability generates a risk against which the security requires a certain level of cash that the specified values correspond to the formula $R(g)$. Most important, however, is that this formula allows us to calculate the value of $R(g)$ only on the assumption that the expected income and probabilities are known and it reflects the minimum level of assets, which an investor must have, 
so that over a long period of time the investment has not led him/her to bankruptcy. It is therefore a critical value, which allows the following interpretation:

- if the level of assets (or cash) is lower than the value of $R(g)$ - the investment is too risky, and in the long term leading to its bankruptcy,

- if the value of $R(g)$ is equal to or lower than this level - the investment is acceptable and causing an increase in wealth in the long term.

This justifies that the Foster-Hart model was considered the only useful tool to support the process of taking control over companies, as it allows the fact of bankruptcy. The only problem lies in the fact that in this process, the difficulty is associated with determining the expected revenue for the acquiring company resulting from the acquisition of control. So we say about the possible income that it will occur in the future, after the acquisition, and whose negative values may expose the bankruptcy. Analysing the principles of the construction of corporate financial statements prepared in accordance with IAS 1 (IFRS) it was recognized that the value of EPS can be considered as an equivalent of income, in the theory of FosterHart, which can be applied in the proposed scheme. Such an assumption may be regarded as justified on the grounds that:

- the connection understood that way may generate losses, and therefore it is covered by a net profit,

- EPS determines the value per share, therefore, the proposed approach will determine how many shares a company can buy, in order not to become bankrupt (this is determined by the value of cash),

- it does not take into account the synergies, but the ability to raise the profitability of the company, which from the point of view of shareholders is the most important because it increases the probability of increasing the dividend per share,

- it does not take into account the number of shares issued by the acquiring company, but by the acquired one, which allows to take into account the relationship of the price of the shares acquired with the future value of EPS,

- negative values of EPS in the long term lead to a significant reduction of the value of equity, which at the loss of liquidity may be a harbinger of the imminent bankruptcy,

- the proposed approach takes into account the profitability of the company after the acquisition.

The scheme, which would allow for the analysis of acquisitions at an angle to avoid bankruptcy after the merger, needs from the above presented reasons to take into account the value of $R(g)$, and it requires the calculation of:

- the value of $R(g)$ for one share of the acquired company, taking into account the future value of EPS after the possible acquisition of control,

- the amount (labelled as Z), which is necessary for the acquisition of the entire shareholding of the company being acquired without fear of bankruptcy,

- the number of shares (labelled as $A$ ), which can be purchased as the purchase of a complete package of shares may not be possible with no debt (or additional issue of shares), 
- the calculation of the percentage share (labelled as Y), which the company can take without any fear of bankruptcy and verifying if that exerts any control (significant impact),

- the amount (labelled as $B$ ) that can be used for the purchase of a predetermined packet (Y),

- the hedge reserve from the bankruptcy (labelled as $C$ ), which the acquiring company should maintain in a given period (for example, annual, after which the value of EPS will be calculated again).

The proposed scheme takes into account the expected value of the EPS with the main assumption of the theory of Foster-Hart, that the $g$, when multiplied by the probability, will allow to obtain a positive number (Foster, Hart, 2009, pp. 785-814). It is easy to conclude that this diagram assumes that if we get a negative number, it cannot be applied, and thereby forgoing the call.

\section{A theoretical example of taking control}

The presentation of the described scheme should be illustrated with the theoretical example of a hypothetical taking control of one of the previously characterized companies. It was assumed in this case that the acquisition company (Y) also occurs at the current market prices of shares through the acquisition of control. This means that company $\mathrm{X}$ wants to take over control of company Y, taking into account the possibility of bankruptcy after the transaction and wanting to protect against it. Table 3 shows hypothetical additional data that are necessary for the implementation of the proposed work schedule. It requires identifying future probabilities and assigned them to the future value of the EPS after a business transaction.

\section{Table 3}

Data of the company Y share analysed in terms of the application of the Foster-Hart formula

\begin{tabular}{lllll}
\cline { 2 - 4 } & Probability & & \\
\hline The purchase price at the beginning & $100 \%$ & & $25 \%$ & $25 \%$ \\
of the first period before the merger & USD 16 & $25 \%$ & USD 12.6 & USD 32.4 \\
\hline $\begin{array}{l}\text { Earnings per share (EPS) at the end } \\
\text { of first period after the merger (g) }\end{array}$ & $25 \%$ & USD -27 & USD -7.2 & \\
\hline $\mathrm{R}(\mathrm{g})$ & USD 91.12 & & & \\
\hline
\end{tabular}

Source: own study.

On the basis of the data presented, there was calculated and presented the hypothetical value $R(g)$, which is unknown in the equation of Foster-Hart:

$$
\frac{1}{4} \log \left(1+\frac{-27}{R(g)}\right)+\frac{1}{4} \log \left(1+\frac{-7.2}{R(g)}\right)+\frac{1}{4} \log \left(1+\frac{12.6}{R(g)}\right)+\frac{1}{4} \log \left(1+\frac{32.4}{R(g)}\right)=0,
$$


hence

$$
R_{g}=91.12 .
$$

Knowing the value of $R(g)$ it should be assumed that it applies to only one share of company $\mathrm{Y}$, which is assigned to it. For this reason, the acquisition of the shares requires the possession of USD 107.12. Knowing this value, first there must be calculated the amount (Z), which is necessary for the acquisition of the entire stake of shares of company $\mathrm{Y}$ :

hence

$$
Z=\operatorname{USD} 107.12 \times 2,000,000,
$$$$
Z=\mathrm{USD} 214,240,000 \text {. }
$$

Since the receiving company has a cash value of USD 54 million, the number of shares (A) needs to be calculated, which can be purchased theoretically in order not to become bankrupt, as an expense of USD 214,240,000 is not possible for it:

$$
A=\operatorname{USD} 54,000,000 / \mathrm{USD} 107.12,
$$

hence

$$
A \approx 504,108 \text {. }
$$

The calculations suggest the purchase of only 504,108 shares of company Y, since any larger number of shares of company $\mathrm{X}$ will expose it to the bankruptcy. It should be noticed that the cash of the acquiring company does not allow for the acquisition of all shares of company Y, but only for the purchase of $25 \%$ (Y), because:

$$
Y=504,108 / 2,000,000,
$$

hence

$$
Y \approx 0.25 \text {. }
$$

The indicated participation shows that company $\mathrm{X}$ can only have an impact on company $\mathrm{Y}$ and cannot control it. Moreover, the amount (B), which can be spent on the acquisition of $25 \%$ of the package, is relatively low, because it is the amount of USD $8,065,728$ :

hence

$$
\begin{gathered}
B=\operatorname{USD} 504,108 \times 16, \\
B=\operatorname{USD} 8,065,728 .
\end{gathered}
$$

The amount, which must be held by the acquiring company as a reserve to protect against bankruptcy (C) can be calculated easily:

$$
\begin{array}{ll} 
& C=\mathrm{USD} 504,108 \times 91.12, \\
\text { hence } & C=\mathrm{USD} 45,934,320.96 .
\end{array}
$$

The reserve (C) should therefore be maintained by company $\mathrm{X}$ for this purpose, to protect against possible future net losses. However, we should know that this amount is calculated separately for subsequent periods, which followed the merger (a requirement of the theory of Foster-Hart). The company therefore needs to be prepared for the possibility to increase or decrease. 


\section{Conclusions}

Mergers and acquisitions can be considered in theory as particularly attractive for companies because they can effectively and quickly increase their value and enter (or even gain) new markets. Also, tax considerations, and other motifs mentioned in the work can give impetus to conclude these transactions. It was stressed, however, that the connections are quite other than acquisition transactions; therefore, to develop a theoretical scheme that protects against bankruptcy seems to be difficult. In contrast, the transfers, due to their different nature, can now be analysed for such protection. And this is important for many reasons. Firstly, it cannot be concluded that the effects of such transactions will always be positive. Secondly, the high cash outflow may increase the risk of losing financial liquidity. Thirdly, the wealth of shareholders, which refers to the market value of equity, may be reduced by discouraging to conduct such business transactions.

Considering the above, an attempt was undertaken to design the scheme, which would allow for protection against bankruptcy in the process of taking control of a company. It has been shown in the paper that the scheme can be used in the context of determining the number of shares, the acquisition of which will not expose, in theory, to bankruptcy. Of course, essential assumptions are those on which this chart is based. And these include even the predicted EPS, which in certain probabilities can be achieved after the acquisition. In addition, it is shown that the proposed approach to acquisitions allows determining the reserve which the acquiring company should maintain for a certain period of time, after which it should once again perform the proposed calculations for the re-calculation of the reserve. In closing, it can be added that the presented concept can be considered as a contribution to separate studies and considered as an introduction to the discussion of the matter. The presented problem of bankruptcy after acquisition may in fact be taken from a theoretical as well as an empirical point of view.

\section{References}

Ahuja, G., Katila, R. (2001). Technological acquisitions and the innovation performance of acquiring firms, A longitudinal study. Strategic Management Journal, 22, 197-220.

Damodaran, A. (2007). Finanse koroporacyjne. Teoria i praktyka. Gliwice: Helion.

Dickerson, A., Gibson, H., Tsakalotos, E. (1997). The impact of acquisitions on company performance: Evidence from a large panel of UK firms. Oxford Economic Papers: New Series, 49, 344-361.

Foster, D.P., Hart S. (2009). An operational measure of riskiness. Journal of Political Economy, 117 (5), $785-814$.

Frąckowiak, W. (ed.). (1998). Fuzje i przejęcia przedsiębiorstw. Warszawa: PWE.

Halicki, M. (2016). The Foster-Hart measure as a tool for determining the set of risky portfolios that do not expose the investor to the bankruptcy. Research papers of Wroctaw University of Economics, 450, 205-216.

IAS, IFRS. KNF: http://www.knf.gov.pl/o_nas/wspolpraca_miedzynarodowa/unia/regulacje_i_dokumenty_powiazane/ias_ifrs.html.

Perepeczko, A. (2009). Fuzje i przejęcia - efektywność finansowa. Wyniki badań zagranicznych i krajowych. Szczecin: Uniwersytet Szczeciński.

Roll, R. (1986). The hubris hypothesis of corporate takeovers. The Journal of Business, 59 (2), 197-216.

Surendranath, R.J., Ngo, T.N., Wang, D. (2016). Credit ratings and the premiums paid in mergers and acquisitions. Journal of Empirical Finance, 39, 93-104. 


\section{OCHRONA PRZED BANKRUCTWEM W PROCESACH PRZEJĘĆ}

Streszczenie: $\mathrm{Cel}$ - celem publikacji jest prezentacja schematu, który opracowano dla analiz transakcji przejęć pod kątem ochrony przed bankructwem. Wykazano także, że schemat ten możne być wykorzystywany w ramach obliczania liczby akcji, których nabycie nie będzie narażać w teorii na bankructwo.

Metodologia badania - Dla opracowania proponowanego schematu posłużono się materiałem literaturowym oraz narzędziami bazującymi na inżynierii finansowej, natomiast obliczenia przeprowadzono na danych hipotetycznych.

Wynik - Przeprowadzone kalkulacje wykazały, że proponowany schemat może zostać zastosowany dla oceny transakcji przejmowania spółek, jednakże należy uwzględniać szereg istotnych założeń, które znacząco mogą wpływać na ostateczną ocenę.

Oryginalność/wartość - Opracowanie można uznać za element uzupełniający obecną wiedzę na temat połączeń i przejęć. Można uznać je także jako przyczynek do odrębnych badań ilościowych oraz głos w dyskusji, potrzebnej dla rozwoju obszaru tematyki pracy.

Słowa kluczowe: fuzje, przejęcia, bankructwo, ryzyko, akcje, EPS

\section{Citation}

Halicki, M. (2017). Protection from Bankruptcy in the acquisition process. Finanse, Rynki Finansowe, Ubezpieczenia, 1 (85), 339-349. DOI: 10.18276/frfu.2017.1.85-27. 